\title{
Anabases
}

ANABASES Traditions et réceptions de l'Antiquité

$9 \mid 2009$

Varia

\section{Rostovtzeff and the classical origins of Eurasianism}

\section{Caspar Meyer}

\section{OpenEdition}

Journals

Electronic version

URL: http://journals.openedition.org/anabases/419

DOI: 10.4000/anabases.419

ISSN: 2256-9421

\section{Publisher}

E.R.A.S.M.E.

\section{Printed version}

Date of publication: 1 March 2009

Number of pages: 185-197

ISSN: 1774-4296

\section{Electronic reference}

Caspar Meyer, "Rostovtzeff and the classical origins of Eurasianism », Anabases [Online], 9 | 2009, Online since 01 March 2012, connection on 20 October 2019. URL : http://journals.openedition.org/ anabases/419 ; DOI : 10.4000/anabases.419 
Anabases 9 (2009), p. 185-198.

\section{Rostovtzeff and the classical origins of Eurasianism}

Caspar Meyer

... the tortuous road of history thus led the Russians from Mithraism through Christianity to Marxism.

George Vernadsky, The origins of Russia (Oxford, 1959), p. vi.

The InTROductory QUOTE, from a book preface by one of the most prolific Russian historians of the twentieth century, speaks to an eccentric conception of history, even by the standards of aphoristic wisdom ${ }^{1}$. In George Vladimirovich Vernadsky's (18871973) interpretation Russia had evolved through a threefold developmental sequence of epochs defined by a dominant belief system of unequal and (lately) declining character. That Marxism was strictly a belief, and a fanatic aberrant one at that, is an unsurprising view for an émigré scholar writing in the United States of the McCarthy era. More difficult to explain is the alleged link between Russia and Mithraism, an Orientalizing religious movement unattested outside the Roman empire or Romanoccupied areas of the ancient world.

Vernadsky's statement is a précis of the argument deployed in his book as much as a personalized motto of his school's peculiar brand of historiography, known as

1 An earlier version of this paper was delivered in September 2008 at a journée d'études convened by the Bibliotheca Academica Translationum at the Centre Louis Gernet, Paris. Among the audience I thank in particular Oswyn Murray, Jürgen von Ungern-Sternberg and Thomas Späth for their stimulating discussion and constructive criticism. Jen Baird and Alfonso Moreno read and commented on drafts of the published version. All remaining errors of fact and opinion are my own. 
Eurasianism. The Eurasianists took their name from a geographical understanding of Russian history and identity. Since time immemorial, they claimed, the Eurasian continent had provided the natural conditions for the growth of cultures which, although mixing and merging Asian and European traits, constituted essentially a separate strand of world civilization. They conceived of Eurasia as an independent geographical unit of fundamental ethnic diversity in which Russians had only recently risen to demographic and political pre-eminence.

The Eurasianist school was established in 1921 with a provocative inaugural collection of essays, Exodus to the east ${ }^{2}$. The founding members, often known as the "classical" Eurasianists, were a group of young émigré intellectuals based in Sofia and Prague-Prince Nikolai Sergeevich Trubetskoi, later renowned as the originator of structuralist linguistics, the geographer and economist Petr Savitskii, the music critic Petr Suvchinskii, and the theologian and philosopher Georgii Florovskii ${ }^{3}$. Vernadsky joined this circle after his arrival in Prague in the following year and quickly emerged as its most productive member developing a coherent Eurasianist conception of Russian history ${ }^{4}$. The numerous Eurasianist writings that appeared in the 1920s and 1930s have attracted great attention in recent scholarship due to their originality as much as their political programme which had gradually assumed centre stage among some of the school's proponents. This programme envisaged the Bolshevik regime as a temporary but necessary cataclysm paving the way to a pan-Eurasian ideocratic state. According to doctrinaire Eurasianists, the vast ecological zone of Eurasia conditioned its diverse inhabitants to rally under a central authority and periodically restore a timeless steppe empire in changing historical guises. The Russian empire was a natural successor to the Mongol empire of Genghis Khan and tended, like its predecessor, towards antagonism

2 Iskhod $k$ vostoku. Predchuvstviya $i$ sversheniya. Utverzhdenie evraziitsev, Sofia, 1921, available in translation under Exodus to the east: forebodings and events: an affirmation of the Eurasians, tr. I. VINKOVETSKY, Idyllwild, CA. 1996.

3 For expositions of the background and significance of Eurasianism, see O. Böss, Die Lehre der Eurasier. Ein Beitrag zur russischen Ideengeschichte des 20. Jahrhunderts, Wiesbaden, 1961; N. Riasanovsky, "The emergence of Eurasianism", California Slavic Studies 4 (1967), p. 39-72; I. VinKovetsky, "Classical Eurasianism and its legacy", CanadianAmerican Slavic Studies 34 (2000), p. 125-139; E. Chinyaeva, Russians outside Russia: the émigré community in Czechoslovakia, 1918-1938, Munich, 2001, 185-198; M. BASSIN, "Classical Eurasianism and the geopolitics of Russian identity", Ab Imperio 2 (2003), p. 257-267. For translations of N.S. Trubetskoi's most important works, see The Legacy of Genghis Khan and other essays on Russia's identity, ed. A. Liberman, Ann Arbor, 1991.

4 D. Овоlensky, "George Vernadsky as a historian of ancient and medieval Russia", in A.D. Ferguson and A. Levin (eds.), Essays in Russian history: a collection dedicated to George Vernadsky, Hamden, CT. 1964, p. 1-17; N. Andreyev, "Appendix I: G.V. Vernadsky", in G.V. Vernadsky (ed.), Russian historiography, Belmont, MA. 1978, p. 512-526; C.J. Halperin, "George Vernadsky, Eurasianism, the Mongols, and Russia", Slavic Review 41 (1982), p. 477-493. 
with the "Romano-Germanic" west. Post-Bolshevik Russia would be the ultimate manifestation of this Eurasian "geopolitical destiny" and its leadership should logically be entrusted to those who recognized the country's essence and providential role.

Unsurprisingly, Eurasianist ideas enjoyed a colourful afterlife among Russian nationalists. Indeed, when I first embarked on the subject I could not have predicted, and never hoped, that Russia's Eurasian ambitions would once again feature as the issue of the day. Against this degradation of Eurasianist ideas currently in evidence, I would like to concentrate on the positive contributions to historical scholarship with which the early movement is generally credited. Previous studies on the subject have focused on the psychological and political roots of Eurasianist thought in German environmentalism and the disillusionment with the perceived rationalism and artifice of western culture, which turned from brooding to toxic with the advance of German aggression in World War I. However, the immediate historiographical context from which the early movement sprang has been neglected, leaving historians of modern Russia to guess at the origins of the school's most notable departure from previous scholarship: namely, the radical reappraisal of cultural interaction with Asiatic nomads in the formation of Russian culture and statehood, of which Vernadsky's reassessment of the "Mongol yoke" represents the prime example.

Vernadsky himself was in fact quite clear about his inspiration. In the introduction to his multi-volume History of Russia (1943), he appraised Iranians and Greeks in South Russia (1922) by his St. Petersburg teacher Michael Ivanovich Rostovtzeff (18701952) as a turning-point in Russian historiography, the first book to examine, in his words, "the earliest trends in the history of Russia 5".

My essay explores the sources of Rostovtzeff's conception of northern Black Sea antiquity, and the possibilities it held out for Russian historiography and national self-identification. I do not wish to suggest that Rostovtzeff was an Eurasianist avant la chose; nor can he be held responsible for the capricious afterlife of his work. On the vital questions of Russian history, the role of the monarchy and the assessment of the Bolshevik coup, Eurasianist views diverged diametrically from those of Rostovtzeff and most other émigrés. Nevertheless, as a historian of Russia's nomadic and Eurasian roots Rostovtzeff offered several attractive propositions, based as they were on a rigorously researched and ostensibly objective foundation of archaeological fact. Thus, despite the political excesses of Eurasianism, the Eurasian viewpoint as elaborated by Vernadsky offered enough substance and common interest to invite Rostovtzeff s praise, above all because it took seriously the fact that:

Geographically and from the cultural point of view, Russia-closely connected as it is with Central Europe-is still more closely connected with a large portion of Asia and with its peculiar cultural development. We must not forget that for centuries of her 
early history Russia formed a constituent part of large and powerful Asiatic-Iranian and Mongolian-empires, that Russia emerged as one of the European states after a long and difficult struggle against them, and that Russia still occupies territorially a large part of Asia $^{6}$.

The reason why this connection between Rostovtzeff and Eurasianism has not been further examined must be that historians of Russia now tend to perceive classical antiquity as marginal or irrelevant to their subject, whereas classicists have generally been preoccupied with Rostovtzeff s books on Roman and Hellenistic history written in American exile, and the biography that is seen to lie behind the wilful anachronisms of his interpretations ${ }^{7}$. Neither discipline had much reason to analyse the last chapter of Iranians and Greeks, entitled "The origin of the Russian state on the Dnieper", where he recapitulates the book's central thesis ${ }^{8}$.

Rostovtzeff describes the northern Black Sea region as a geographical unit, characterized by the great river routes and their connective potential between the Eurasian steppe belt and the Black and Aegean Seas. The region encouraged its inhabitants over millennia to adopt particular patterns of settlement and economy. Its civilizing potential was optimally realized when the steppe was dominated by a warrior elite, under whose political control the sedentary agriculturalists on the shores and riverbanks could exploit the abundant natural resources mentioned by ancient authors and conduct a water-borne trade. This cultural symbiosis achieved its exemplary expression in the relations between Scythians and Greeks in the fifth and fourth centuries BC. According to Rostovtzeff, this "Greco-Iranian" type of society defined the framework for all subsequent civilizing processes in the northern Black Sea area, the role of the Scythians being taken successively by Sarmatians, Celts, Goths and Huns, each of which entered pre-existing relationships with sedentary communities. When the Slavs migrated into the region in the sixth century $\mathrm{AD}$, they adopted accordingly the cultural and politi-

6 From Rostovtzeffs preface to G. Vernadsky, A history of Russia, New Haven, 1929, p. $x$.

7 Even in Marinus Wes' detailed exploration of Rostovtzeff s Russian years, the impact of his milieu is sought exclusively in his later works written in America; see M. WES, "The Russian background of the young Michael Rostovtzeff", Historia 37 (1988), p. 207-221 and idem, Michael Rostovtzeff, historian in exile. Historia Einzelschriften 6, Stuttgart, 1990. If considered at all, his previous writings on northern Black Sea archaeology are described (quite misleadingly, as I shall argue) as "...carefully nuanced... free of the larger theorizing and dogmatic conclusions that tended to overtake Rostovtzeff in his writings of the twenties and thirties"; see G.W. Bowersock, "The South Russia of Rostovtzeff", in H. Heinen (ed.), M. Rostowzew, Skythien und der Bosporus, Band II. Wiederentdeckte Kapitel und Verwandtes, Stuttgart, 1993, p. 191.

8 M. RostovtzefF, Iranians and Greeks in South Russia, Oxford, 1922, p. 210-222, re-published in the Annual Report of the American Historical Association 1920 (1925), p. 165-171. One of the few studies to comment on this chapter is that of J. Andreau, in M.I. RostovtzeFF, Histoire économique et sociale de l'empire romain, trans. O. Demange, Paris, 1988, p. lix-lx. 
cal traditions of their predecessors and fulfilled the region's potential by inviting the protection of a Scandinavian warrior elite, the Varangians:

Thus they founded in South Russia a state of the same type as the Germans [i.e. the Goths] before them, and naturally inherited from them their towns, their trade relations, and their civilization. This civilization was not, of course, a German one, but the ancient Greco-Iranian civilization of the Scythians and the Sarmatians, slightly modified ${ }^{\text {. }}$

In essence he argued for a continuity between ancient and modern history:

It is a mistake to begin the history of Russia with the Russian annals in the ninth century, that is, to confound the history of Russia with the history of the Slavonic race. The history of Russia as an economic and political organism is much more ancient than the earliest references to the Slavonic race. Russia as a country existed long before the ninth century, and formed part of the civilized world even in the classical period and in the period of migrations. At this epoch the main lines of the future evolution of the country were already laid down ${ }^{10}$.

Iranians and Greeks was Rostovtzeff s first work to display that aptitude for holistic vision more commonly associated with his histories of the Roman empire (1926) and the Hellenistic world (1941). It was also Rostovtzeff s first English-language monograph, written immediately after his emigration, mostly in Oxford with the editorial assistance of John D. Beazley ${ }^{11}$. Judging by its reviews ${ }^{12}$, it was well received, much better than the Russian original Ellinstvo i iranstvo na yuge Rossii (Hellenism and Iranism in South Russia), which appeared in Petrograd in 1918, within days of Rostovtzeff s terminal departure from his native country. To readers of the Russian version, who were better acquainted with Russian historiography, the pervasive political bias of Rostovtzeff s thesis was entirely obvious. His account of the origins of the Russian state in the willing acceptance by the Slavs of Varangian rule was nothing but an obstinate repetition of old Slavonic annalistic literature, demonstratively unconcerned by recent

9 RostovtzefF, Iranians, p. 219.

$10 \quad$ Ibid., p. 211.

11 On the genesis of the book, see V. Yu Zuev, "Der Schaffensweg M.I. Rostovtzeff s. Zur Entstehung der 'Untersuchung zur Geschichte Skythiens und des Bosporanischen Reiches'”, in H. Heinen (ed.), Rostowzew, 169-186; G.M. Bongard-Levin, "M.I. Rostovtzeff in England", in G.R. Tsetskhladze (ed.), Ancient Greeks west and east, Leiden, 1999, p. 21-29; idem, "E.H. Minns and M.I. Rostovtzeff: glimpses of a Scythian friendship", in D. Braund (ed.), Scythians and Greeks: cultural interactions in Scythia, Athens and the early Roman empire, Exeter, 2005, p. 13-32.

12 D.M. Robinson, Art Bulletin 5 (1922), p. 48-50; idem, American Historical Review 29 (1923), p. 114-116; P. Gardner, Classical Review 37 (1923), p. 78-79; E.H. Minns, Journal of Hellenic Studies 43 (1923), p. 84-86. 
source criticism and claims to Ukrainian cultural independence ${ }^{13}$. In this respect his approach resembled the monarchical tradition widely popularized in Russia since Nikolai Karamzin's post-Napoleonic treatment, which identified Russian history with the history of its ruling dynasty and represented its autocratic outlook as an intrinsic and constructive force in the destiny of the empire ${ }^{14}$.

In the Russian version Rostovtzeff's overarching argument was set out pre-emptively in the introduction:

It seems a priori incomprehensible and cannot be understood, why there should exist a connection between our culture and history, and those of the Greeks and the Iranians, who occupied South Russia in an epoch in which we know nothing at all about Slavs and Russians. Nevertheless, this connection does exist, not in ethnography or in politics, but in culture, a connection of continuity; it determined the cultural particularities and way of life of what would later become Russia in the earliest times of the existence of this region of the civilized world ${ }^{15}$.

The original stimulus for Rostovtzeff's work on the northern Black Sea region can be reconstructed from his bibliography. Previously known as a specialist of Roman agrarian history, Rostovtzeff had turned his attention to northern Black Sea archaeology abruptly in the early 1910s when a continuous series of publications on Scythian religion and ideas of power set in. His first known discussion of the subject goes back to a lecture read in March 1912 at a meeting of the St. Petersburg Imperial Archaeological Commission and published in the following year in a substantial article entitled "The conception of monarchical power in Scythia and on the Bosporus ${ }^{16 "}$. His argument

13 For the Ukrainian reception, see M. HRusHEvSKY's review in Ukraina 4 (1925), p. 151-159, with S. PlokHY, Unmaking imperial Russia: Mykhailo Hrushevsky and the writing of Ukrainian history, Toronto, 2005, p. 117-119, 151. Indicative also are the negative comments by Rostovtzeff's former teacher N.P. Kondakov in a letter to the archaeologist S.A. Zhebelev, published in I.P. Medvedev and I. TunkinA (eds.), Mir russkoi vizantinistiki: materialy arkhivov Sankt-Peterburga [The world of Russian Byzantinists: materials from the archives of St. Petersburg], St. Petersburg, 2004, p. 739, n 44 (Prague, 25 November 1924).

N.M. KaramzIn, Istoriya gosudarstva rossiiskogo [History of the Russian state], vols. I-XII (St. Petersburg, 1816-1829). Karamzin, although glossing over the Varangian problem by speaking vaguely of an "admixture", anticipated Rostovtzeff in seeing the Scythians as plausible precursors of Russian history; see A.G MAzour, Modern Russian historiography, rev. ed., Westport, CT. 1975, p. 82.

M.I. RostovtzefF, Ellinstvo i iranstvo na yuge Rossii, Petrograd, 1918, ed. Moscow, 2002, p. 7.

16 M.I. RostovtzefF, "Predstavlenie o monarkhicheskoi vlasti v Skifii i na Bospore", Izvestiya Imperatorskoi Arkheologicheskoi Komissii [Bulletin of the Imperial Archaeological Commission] 49 (1913), p. 1-62, 133-140. For the background and bias of this essay, see V. Yu. Zuev's and I.A. LevinSKAYA's important commentary on Rostovtzeff s "Iranskii konnyi bog i yug Rossii [The Iranian rider god and South Russia]", in H. Heinen (ed.), 
focused on the iconographical interpretation of a fourth-century BC silver rhyton from the Karagodeuashkh kurgan near Krymsk, on the Asiatic side of the Kerch straits [fig. 1]. The piece had been excavated more than twenty years earlier, but the relief on the surface became intelligible only during restoration work in the Imperial Hermitage. It shows two horsemen in Scythian dress, the one to the left holding a rhyton and a staff, the other raising his right hand. On the ground lie two beheaded bodies in Scythian dress, one beneath each horse. Rostovtzeff identified the staff of the left horseman as a sceptre and the gesture of the rider opposite as an adoratio-though not an adoratio in the conventional sense of the term, showing a vassal greeting his king. Compositional resemblances to Sasanian rock reliefs at Naqsh-i-Rustam, Iran, showing the royal investitures of Ardashir I and Bahram I by Ahura Mazda [fig. 2], prompted Rostovtzeff to interpret the scene as a ritual conferral of royal powers by the supreme god through a sacred beverage. Thus, by inferring a continuity in meaning, the rhyton opened a window on political history and the ideological structures of ancient monarchy in the northern Black Sea region:

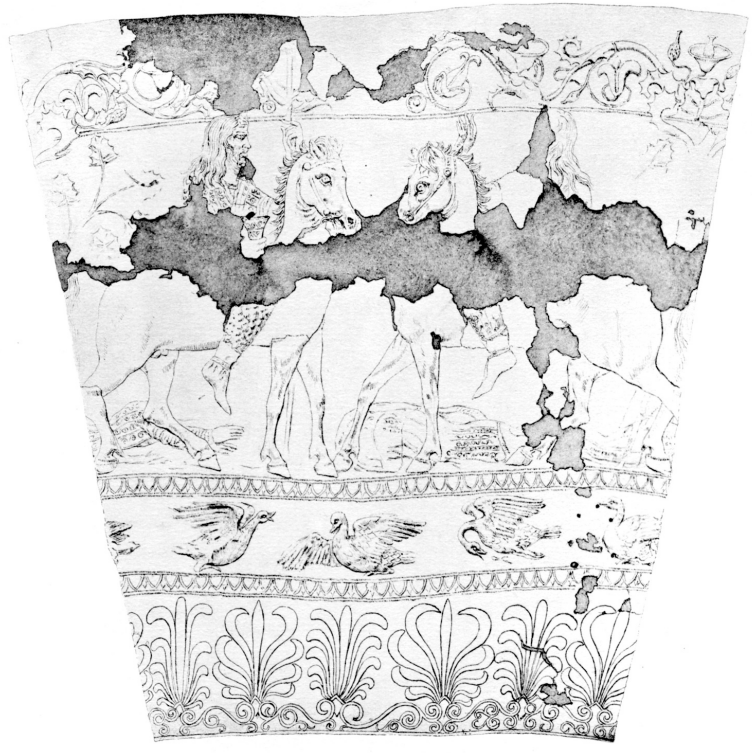

Fig 1. Silver rhyton from Karagodeuashkh kurgan with engravings of two mounted figures and water birds. Length $62.2 \mathrm{~cm}$. St. Petersburg, State Hermitage Museum. Drawing after Rostovtzeff, IAK(1913), pl. 1.

Rostowzew, p. 164-167. For the archaeological context of the rhyton, see A.S. LAPPODANILEVSKII, "Drevnosti kurgana Karagodeuashkh, kak materialy dlya bytovoi istorii Prikubanskogo kraya v IV-III vv. do n.e. [Antiquities from Karagodeuashkh kurgan, as materials for cultural history in the Prikuban territory in the fourth to third centuries BC]", Materialy po Arkheologii Rossii [Materials on the Archaeology of Russia] 13 (1894). 
The comparison we made gives us monumental and unshakeable confirmation of the fact that the Scythian kingdoms... aspired to organize themselves on the very same [theocratic] structure and on the same [Iranian] religious basis as the kingdoms of Cappadocia, Commagene, Armenia, Iberia, Albania, and finally Parthia. [...]

In accordance with this tradition... the authority of the king was sacred, since his power was conferred on him by god, by whose will he was called to the throne. The rule of the monarch was by the grace of the creator of the sky and the earth.

The doctrine raised the monarch aloft and gave him the likeness of divinity, endowed him so to speak with rights equal to those of a god, without separating him from the people. Owing to this peculiarity the doctrine remained supremely attractive and compelling even millennia after its creation ${ }^{17}$.

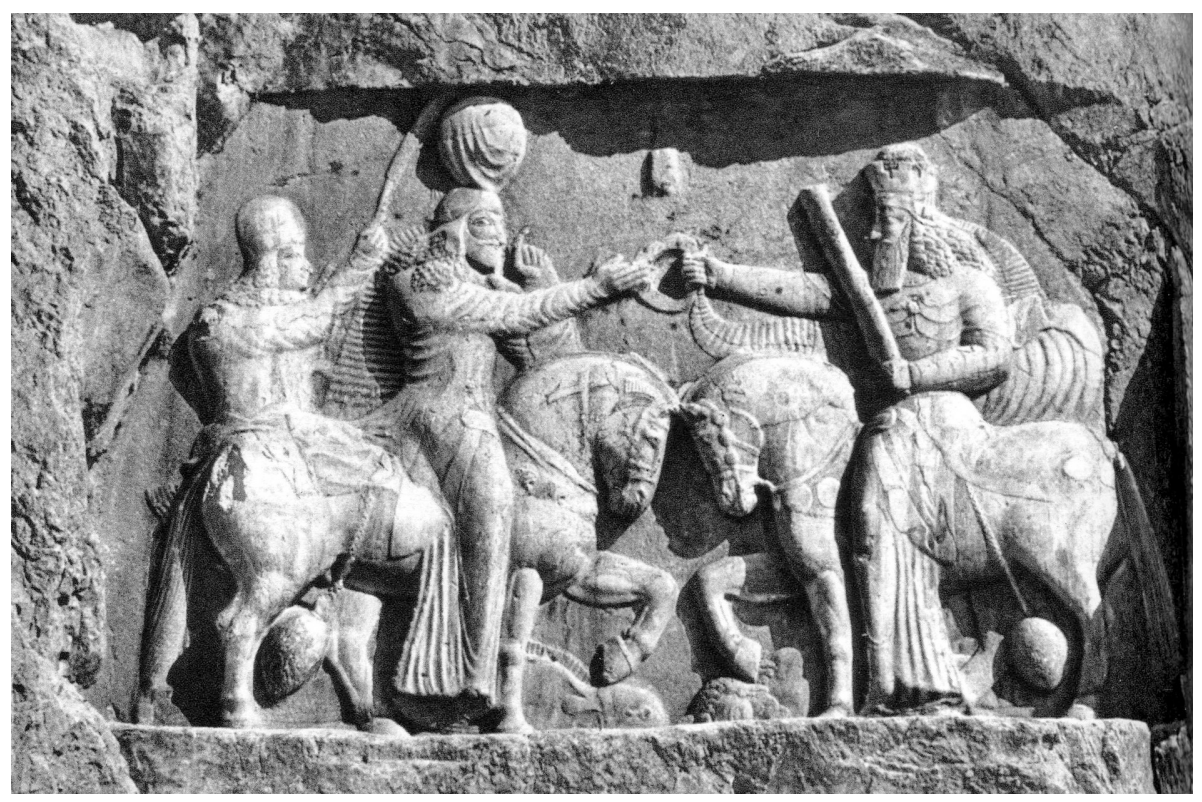

Fig. 2. Rock relief at Naqsh-i-Rustam, Iran, showing the investiture of Ardashir I by Ahura Mazda in AD 224. Photograph R. Winkler.

To all appearances, Rostovtzeff had experienced a moment of profound revelation when the relief on the rhyton re-emerged under the hands of a skilled conservator. The idea that cultural influence from Iran had established a transferable ideal type of society, consonant with the natural proclivities of Eurasian ecology, became the motif and motive factor of his research on the northern Black Sea region, of which Iranians 
and Greeks is the crowning moment. Revealingly, the most frequently cited book in Rostovtzeff s initial study is Franz Cumont's Mystères de Mithra, which was accessible to him in the German translation of 1903. Cumont's influence is evident in the ingenious religious interpretations of visual sources. The article provides the earliest indication known to me for Rostovtzeff's exposure to Cumont's work and throws an interesting light on the later friendship between the two. But what made a Russian of the late tsarist empire pick up Cumont's book in the first place?

The Russian present in which Rostovtzeff had written his study was one of gloomy presentiment among the educated elite. By the early 1910s many of the liberal advances of the 1905 Revolution had been clawed back through reactionary intervention into state affairs, critically so in June 1907 when the Minister of the Interior Petr Stolypin dissolved the Duma and altered the electoral laws by imperial decree. The recognition among the moderate elements of the bourgeoisie and the intelligentsia that the temporary disruption of state authority had posed a threat to them and to the possibility of peaceful reform gradually undermined the broad coalition among the classes that had sustained the political activism and mass strikes of the previous years. With the economic upswing of 1909, life in St. Petersburg regained a tolerable measure of material comfort and breathing space for self-reflection. Recent events had confirmed that the success of a full-scale revolution would depend on the participation of the countryside, but even some of the radical ringleaders had grown wary of its lack of political sophistication. An uprising of millions of peasants who cared more for instant "justice" than socialism or democracy would inevitably descend into a massacre with unspeakable consequences for civilized life in Russia. Realists came to conclude that, under the present circumstances, no educational initiative, however well-intended, could defuse the suspicion and outright contempt with which the peasantry viewed the urban elite. This dilemma acted as a litmus test separating diehard revolutionaries from liberal reformers and foreshadowing the split at the centre of the political landscape, which paved the way to the victory of the extreme left. The spectre of a total social conflagration produced some of the most penetrating and terrifying moments of Russian intellectual history, as exemplified by the poetry of Alexander Blok and the $V e k h i$, or Landmarks, essays ${ }^{18}$. As liberals depending on state patronage, many academics became entrenched and conceived of themselves and the universities as oases in a desert of barbarism-a perspective that could not fail to have a profound impact on their work. A common interest across the disciplines was to explore Russia's religious foundations so as to overcome the pernicious materialism and nihilism, and initiate the country's spiritual regeneration from the individual upwards.

In this mystic upsurge it would not have been too far-fetched for an ancient historian to turn to the Hellenistic Mediterranean, or rather Johann Gustav Droysen's

18 This context has been vividly described by WES, Rostovtzeff, 59-74, although from the perspective of Rostovtzeff s post- rather than pre-Revolutionary scholarship. 
interpretation of it, to discover spiritual beginnings. As is well known, since Droysen's (literally) epoch-making Geschichte des Hellenismus (1836-1843) it was widely taken for granted that the cultural interaction between Greeks and "Orientals" after Alexander's death had somehow prepared the conditions for the spread of Christianity-a teleology that risks downplaying the role of Judaism, as Momigliano stressed ${ }^{19}$. Although variously restated, Droysen's programmatic thesis remained essentially undocumented. While writing his own book on the Hellenistic world, Rostovtzeff must at some point have realized that for the sake of consistency he had to leave aside religious history and focus instead on the economic behaviour of the "bourgeoisie"-the only theme holding together his examination of political history (i.e. the effects of Roman intervention in the Hellenistic east in chapters III-VII) and of social developments ("Summary and Epilogue") ${ }^{20}$. But that he never entirely relinquished the position seems to be borne out by his Ingersoll Lecture of 1938, in which he developed a complementary history of religious mentality fully in keeping with Droysen's ideas. According to this account the social and economic crisis in the Hellenistic east after the rise of Rome encouraged the Greeks to abandon their traditional polis cults for those of the local populations, which promised salvation, life after death, and resurrection:

In this atmosphere of religious excitement and expectation, of revelation and mystery, there appeared in Palestine the last great manifestation of Hellenistic mentality in the Christian religion ${ }^{21}$.

Cumont's work on the diffusion of Oriental mystery cults in the Roman empire offered at the time by far the most convincing attempt to fill the gap left by Droysen ${ }^{22}$. Cumont and Rostovtzeff shared similar aims and problems: both wished to write a long-term history of the spiritual foundations of their respective countries; both agreed

19 A. Momigliano, "J.G. Droysen: between Greeks and Jews", Essays in ancient and modern historiography, Middletown, CT. 1977, p. 307-323; idem, "Hellenismus und Gnosis", Saeculum 21 (1970), p. 185-188; and recently P. PAYEN, "Les 'religions orientales' au laboratoire de l'Hellénisme: 1. Johann Gustav Droysen”, Archiv für Religionsgeschichte 8 (2006), p. 163-180.

20 M.I. RostovtzefF, The social and economic history of the Hellenistic world, vols. I-III, Oxford, 1941, with A. Momigliano, "Rostovtzeff s twofold history of the Hellenistic world”, Journal of Hellenic Studies 63 (1943), p. 116-117.

21 M.I. RostovtzefF, "The mentality of the Hellenistic world and the after-life", Ingersoll Lecture, Harvard University, 26 April 1938, Cambridge, MA. 1938, p. 25.

Among the historiographical studies of Cumontian diffusionism, see especially R.L. Gordon, "Franz Cumont and the doctrines of Mithraism", in J.D. Hinnells (ed.), Mithraic studies I, Manchester, 1975, p. 215-248; R. ВЕСК, The religion of the Mithras cult in the Roman empire, Oxford, 2006, p. 50-56; C. Bonnet, "Les 'religions orientales' au laboratoire de l'Hellénisme: 2. Franz Cumont", Archiv für Religionsgeschichte 8 (2006), p. 181-205; and the introduction and commentaries by C. BONNET and F. van HAEPEREN in F. Cumont, Les religions orientales dans le paganisme romain, vol. I, Turin, 2006. 
that these foundations could be explained only by reference to a period of prolonged exposure and assimilation to Oriental religion; and both were dealing with archaeological material that appeared to attest to such a period, although the corresponding literary sources were not forthcoming. Both solved this problem by adopting a strictly diffusionist model of cultural change and connected the supposed evidence for Oriental influence with migrations or religious diasporas, which allowed them to write a historical description that met the standards of contemporary scholarly discourse. Rostovtzeff and Cumont were kindred spirits and entered into a lifelong friendship ${ }^{23}$. Their shared conviction in religious diffusion culminated in the excavations at DuraEuropos, initiated by Cumont in 1922/3, and continued from 1937 by Rostovtzeff s home institution, Yale University. The project's implicit goal was obviously to uncover the missing link between western Mithraism and Persian Zoroastrianism. The link remains elusive and probably never existed.

To Rostovtzeff, the Aryanizing account of the rise of Christianity was attractive because it suggested the possibility of a longue durée account of Russia's origins and spiritual nature. Even though no part of Russia had ever been integrated into the political structures of the Hellenistic world or Rome, its soil proved fertile for the spread of Christianity for it had been prepared by historical conditions in the southern provinces anticipating those of Hellenism in the Mediterranean. The fusion of Greek and Iranian culture in the northern Pontic steppe allowed Rostovtzeff to link the rise of Christianity to the "fundamental" historical forces of society and economy, without recourse to the "anecdotal" accounts of conversion in the sources, which are barely mentioned in his work. The notion of a Greco-Iranian past offered an original explanation of Russia's ambiguous identity between Asia and Europe-at the forefront of civilization and Christianity but independent of the west.

This study could easily have been about Rostovtzeff and the Russian reception of Cumont. But I conceived my essay intentionally to offer an unexpected perspective on Rostovtzeff, one that distances us from the ancient historian about whom so much has been written recently and foregrounds instead his work as an archaeologist with deep patriotic attachments. The role of visual evidence from Greco-Scythian metalwork in his synthesis cannot be overestimated. It offered the seemingly concrete facts that allowed Rostovtzeff to flesh out the bare bones of material culture with historical meaning and demonstrate the long-term cultural continuities he had set out to discover. Rostovtzeff s handling of the iconographical evidence provided the foundational impetus for a thriving sub-discipline of Eurasian archaeology, concerned with the religion

23 Their abundant correspondence is now available in G.M. Bongard-LEVIN and Yu. N. Litvinenko (eds.), Parfyanskii vystrel [The Parthian shot], Moscow, 2003, p. 19-259; G. Bongard-Levine, C. Bonnet, Yu. Litvinenko and A. Marcone (eds.), Mongolus Syrio salutem optimam dat: la correspondance entre Mikhaïl Rostovtzeff et Franz Cumont. Mémoires de l'Académie des Inscriptions et Belles-Lettres 36, Paris, 2006. 
and mythology of the Scythians. The professed "Iranism" of Scythian culture continues to provide an overarching interpretative framework whose premises are hardly ever questioned or indeed fully understood. Among the few critics of Rostovtzeff s interpretation of the Karagodeuashkh rhyton, V. Yu. Zuev and I.A. Levinskaya rightly stressed the change in the attributes held by the horsemen on the vessel and in the rock reliefs, and the absence of a continuous chain of iconographical transmission over the five centuries separating classical Bosporus from Sasanian Persia ${ }^{24}$. Furthermore, the scene on the rhyton shows no divine or royal attributes. The staff held by the left rider is surely a lance not a sceptre, which would be much shorter and clearly distinguished, in both Greek and Bosporan iconography, by an ornamental finial at the top and ribbons on the handle ${ }^{25}$. The meeting between god and mortal, if this is really what the rhyton is meant to show, is hardly identifiable in visual terms: in fact, we cannot be sure whether the similarity between the images is purely compositional, with our piece depicting the benefits of friendship ties among horse-borne nobility in a strikingly lucid narrative formula.

Such a subject would be consistent with what we know about the function of Greco-Scythian metalwork. Objects of this class, personal ornaments and processional arms with Scythian genre scenes, were produced for a short period in the fourth century BC. The distribution of finds in Bosporan and Scythian tombs, and iconographical borrowings from the Bosporan numismatic repertoire, suggest production in Bosporan cities, as Rostovtzeff had pointed out ${ }^{26}$, from where the objects reached the kurgans of the outlying steppe as gifts in return for services and manpower. So much can be deduced from the few snippets of Bosporan local history preserved in Polyaenus and Diodorus Siculus. For instance, when the Bosporan ruler Gorgippus (389-349/8 BC) succeeded to the throne in the midst of a complicated dynastic war with the Maeotian princess Tirgatao, he was forced to sue for peace, which was granted on offering a "very great gift ${ }^{27}$ ". In the war against neighbouring Theodosia, Gorgippus' brother Leucon I (389-349/8) is said to have lined up Scythian archers behind his infantry with express orders to shoot his own men if they abandoned their position ${ }^{28}$.

24 V. YU. Zuev and I.A. LeVinskaya in H. Heinen (ed.), Rostowzew, p. 164-165.

25 S.v. "Sceptrum" in M.E. SAGLIO and M.E. PotTIER (eds.), Dictionnaire des antiquités grecques et romaines, IV, Paris, 1911, p. 1116. The two seated Scythians on the silver cup from Gaimanova Mogila hold sceptres, marked by a ribbon wrapped around the handle; cf. the photograph in R. Rolle, M. Müller-Wille and K. Schietze (eds.), Gold der Steppe: Archäologie in der Ukraine, ex. cat., Neumünster, 1991, p. 375. M.I. RostovtzefF, Skythien und der Bosporus, Berlin, 1931, p. 393-409.

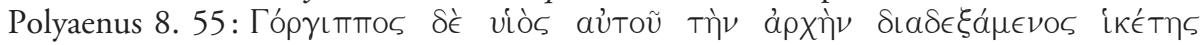

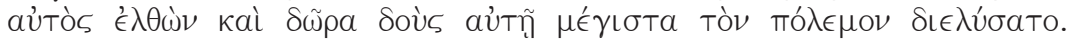
Polyaenus 6. 9. 4: $\Lambda \in \hat{\kappa} \kappa \omega \nu . .$. ор

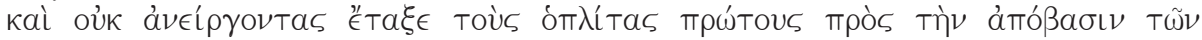

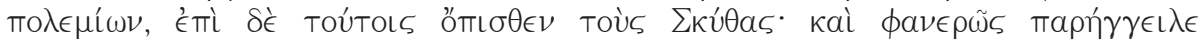


In the internecine strife among his grandsons, the contender Eumelus (310/9-304/3) launched his bid by "concluding a treaty of friendship with some of the barbarians who lived nearby", forcing his brother Satyrus II (311/10-310/9) to call in Scythian allies in great numbers ${ }^{29}$.

The Bosporan kingdom of the classical period was a multi-ethnic conglomerate of coastal cities and tribal lands. At the core of this state was a dynamic system of aristocratic collaboration, under the hegemony of a mixed dynasty, the Spartocids ${ }^{30}$. As epigraphic evidence attests, the Spartocid rulers of the classical period accommodated for cultural differences in their realm by reigning as constitutional leaders (arkhontes) over Greek cities and as kings (basileis) over local tribes. Our rhyton, like many other Greco-Scythian artefacts, articulates the emotional bonds it was meant to establish within this network of cross-cultural communication and cooperation that united sovereigns and allies. Through decorated gifts the Bosporan ruling class disseminated paradigms of conduct in accordance with which the recipients were encouraged to evaluate and transform their own aristocratic behaviour and ethos. Yet Rostovtzeff wanted to connect this powerful fiction of altruistic elite friendship with ideological structures and the "deeper" realities of life in the Eurasian continent. Whether the putative continuity between Iranian and Bosporan religion and ruler ideology "really" existed is doubtful and in many ways beside the point. The crucial fact is that Rostovtzeff recognized definite ideological messages which no one else had seen before. In his understanding, the Bosporan kingdom was an obvious precedent and justification of Russia, and projected the cosmopolitan nature of tsarist monarchy (ruling as emperors over Russians and Asians and as constitutional kings over occupied territories in the west) into the earliest history of Russian lands. He brought the political continuity into existence in a Weberian sense, by adopting it as a motive for individual loyalty and action in the Russian present ${ }^{31}$.

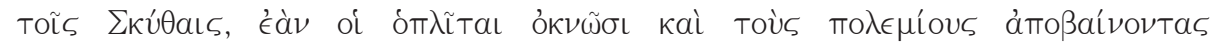

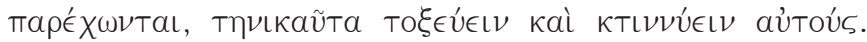

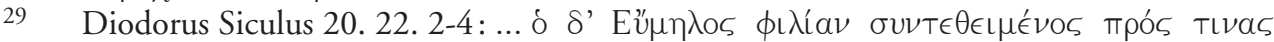

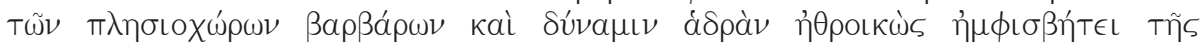

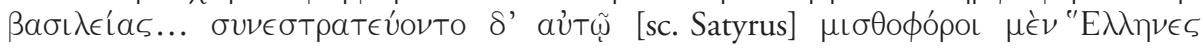

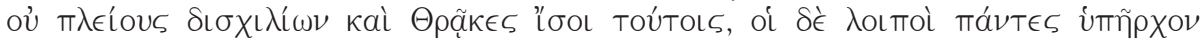

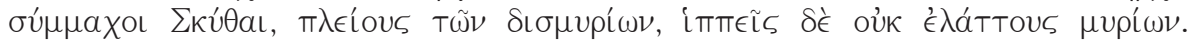

On the Bosporan system of "aristocratic power-sharing", see A. Moreno, Feeding the democracy: the Athenian grain supply in the fifth and fourth centuries BC, Oxford, 2007, p. 169-206, to be read profitably alongside M.I. RostovtzefF, "Kapitel VI. 1: Staat und Gesellschaftsordnung in der Epoche der Spartokiden", in HeInen (ed.), Rostowzew, 70-87 and idem, "The Bosporan kingdom", Cambridge Ancient History VIII: Rome and the Mediterranean, 218-133 B.C., Cambridge, 1930, p. 561-589.

31 I refer to M. WeBER's constructionist sociological tenets formulated in "Über einige Kategorien der verstehenden Soziologie", in Gesammelte Aufä̈tze zur Wissenschaftslehre, Tübingen, 1913, ed. 1988, p. 427-474. 
The Russia Rostovtzeff was born into was the last dynastic empire in the proper sense of the word, and its transformation and destruction endowed him with a productivity and historical awareness rarely seen before or since. His conception of empire was based on the principle of voluntary co-option of non-Russian peoples. It looked back to ideals of the mid-nineteenth century which had long been eclipsed by native-soil nationalism and pan-Slavic unity as the primary referents of Romanov rule. Caught between continents and epochs of world history, Rostovtzeff s scholarship was at a threshold in many respects, inspired by cosmopolitan notions of statehood and commonwealth on the one hand and grounded in European empiricism and positivism on the other. His work on northern Black Sea archaeology reflected this contradictory position in that it combined and integrated an unprecedented volume and typological range of data to lift the perceived essences of Russian historical identity on a seemingly unshakeable footing. The framework he created for exploring Russian history in terms of continuities and naturalistic determination were so compelling that the political centre became conceptually dispensable, or at least exchangeable. So much is clear from the afterlife of his work among the Eurasianists, Vernadsky in particular, who were prepared to intellectually accommodate Bolshevik rule to a degree inconceivable to Rostovtzeff. Rescripted in a manner quite opposite to its original intentions, his work became amenable to the new guarantors of imperial continuity. Rostovtzeffs s most enduring contribution to Russian scholarship is arguably not the sheer mass of evidence he collected and processed, but the inspired visions of pagan tsardom and Aryan Christianity that emerged from his interpretations. He wrote the first scholarly books that gave non-Russians and nomads a meaningful role in the history of Russia and which could therefore not be overlooked by his successors, especially in Russia.

Caspar MEYER

Lecturer in Classical Archaeology

Birkbeck College, University of London

Malet Street, Bloomsbury

London WC1E 7 HX

United Kingdom

h.meyer@bbk.ac.uk 